\title{
The alarmin IL-1a is a master cytokine in acute lung inflammation induced by silica micro- and nanoparticles
}

\author{
Virginie Rabolli ${ }^{1}$, Anissa Alami Badissi ${ }^{1}$, Raynal Devosse ${ }^{1}$, Francine Uwambayinema', Yousof Yakoub ${ }^{1}$, \\ Mihaly Palmai-Pallag ${ }^{1}$, Astrid Lebrun', Valentin De Gussem¹, Isabelle Couillin², Bernard Ryffel ${ }^{2}$, Etienne Marbaix ${ }^{3}$, \\ Dominique Lison ${ }^{1}$ and Franois Huaux ${ }^{1,4^{*}}$
}

\begin{abstract}
Background: Inflammasome-activated IL-1 $\beta$ plays a major role in lung neutrophilic inflammation induced by inhaled silica. However, the exact mechanisms that contribute to the initial production of precursor IL-1 $\beta$ (pro-IL-1 $1 \beta$ ) are still unclear. Here, we assessed the implication of alarmins (IL-1a, IL-33 and HMGB1) in the lung response to silica particles and found that IL-1 $a$ is a master cytokine that regulates IL-1 $\beta$ expression.

Methods: Pro- and mature IL-1 $\beta$ as well as alarmins were assessed by ELISA, Western Blot or qRT-PCR in macrophage cultures and in mouse lung following nano- and micrometric silica exposure. Implication of these immune mediators in the establishment of lung inflammatory responses to silica was investigated in knock-out mice or after antibody blockade by evaluating pulmonary neutrophil counts, CXCR2 expression and degree of histological injury.

Results: We found that the early release of IL-1a and IL-33, but not HMGB1 in alveolar space preceded the lung expression of pro-IL-1 $\beta$ and neutrophilic inflammation in silica-treated mice. In vitro, the production of pro-IL-1 $1 \beta$ by alveolar macrophages was significantly induced by recombinant IL-1a but not by IL-33. Neutralization or deletion of IL-1a reduced IL-1 $\beta$ production and neutrophil accumulation after silica in mice. Finally, IL-1a released by J774 macrophages after in vitro exposure to a range of micro- and nanoparticles of silica was correlated with the degree of lung inflammation induced in vivo by these particles.

Conclusions: We demonstrated that in response to silica exposure, IL-1a is rapidly released from pre-existing stocks in alveolar macrophages and promotes subsequent lung inflammation through the stimulation of IL-1 $\beta$ production. Moreover, we demonstrated that in vitro IL-1a release from macrophages can be used to predict the acute inflammogenic activity of silica micro- and nanoparticles.
\end{abstract}

Keywords: Alarmins, Inflammation, Neutrophils, Silica, Nanoparticles, IL-1 family, Inflammasome

\section{Background}

Inhalation of micrometric and nanometric particles can lead to pulmonary diseases characterized by inflammation, fibrosis and/or cancer. Pulmonary inflammation induced by inhaled particles is characterized by a marked

\footnotetext{
* Correspondence: francois.huaux@uclouvain.be

'Louvain centre for Toxicology and Applied Pharmacology (LTAP), Institut de Recherche Exprimentale et Clinique (IREC), Universit catholique de Louvain, Brussels, Belgium

${ }^{4}$ Louvain centre for Toxicology and Applied Pharmacology (LTAP), Universit catholique de Louvain (UCL), Avenue Mounier 52, B1.52.12, 1200 Brussels, Belgium

Full list of author information is available at the end of the article
}

accumulation of neutrophils which secrete large quantities of reactive oxygen metabolites, granule enzymes and proinflammatory mediators $[1,2]$. It has been demonstrated that the pro-inflammatory cytokine interleukin-1 $\beta$ (IL-1 $\beta$ ) drives particle-induced inflammation by enhancing granulocyte migration and accumulation to inflammatory sites [3-5]. Mature IL-1 $\beta$ release in the extracellular environment requires several steps including the production of the biologically inactive IL- $1 \beta$ pro-form (pro-IL-1 $\beta$ ) consecutive to Illb gene transcription as well as its maturation and exocytosis through the NLRP3 inflammasome machinery. Pro-IL-1 $\beta$ production could result from cellular

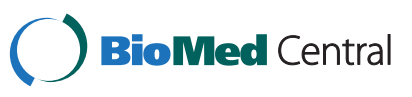

2014 Rabolli et al.; licensee BioMed Central. This is an Open Access article distributed under the terms of the Creative Commons Attribution License (http://creativecommons.org/licenses/by/4.0), which permits unrestricted use, distribution, and reproduction in any medium, provided the original work is properly credited. The Creative Commons Public Domain Dedication waiver (http://creativecommons.org/publicdomain/zero/1.0/) applies to the data made available in this article, unless otherwise stated. 
detection of pathogen components, PAMPs, or from pro-inflammatory cytokines. Also, IL- $1 \beta$ positively autoregulates its own synthesis via NFkb binding activity [6].

Several studies have demonstrated that $\mathrm{K}^{+}$efflux, cytosolic release of lysosomal cathepsins and mitochondriaderived factors such as reactive oxygen species (ROS) are involved in the NLRP3 inflammasome assembly and activation by micro- and nanoparticles [7-11]. It is, however, surprising that the signal(s) triggering NFkbmediated up-regulation of pro-IL-1 $\beta$ after particle exposure remain(s) unknown $[12,13]$. The identification of a common element that initiates pro-IL- $1 \beta$ production in response to particles would be useful to understand their inflammatory properties and to predict their inflammatory potential.

The alarmin family comprises structurally distinct endogenous mediators including defensins, cathelicidins, eosinophil-associated ribonucleases, heat shock proteins (HSP), saposin-like granulysin, ion-binding proteins (e.g., S100 proteins and lactoferrin), and nucleotides/metabolites (e.g., uric acid) [14]. Additionally, some constitutive cytokines that possess intracellular functions such as IL$1 \alpha$, IL-33 and High Mobility Group Box 1 (HMGB1) are also considered as alarmins [5,15-18]. Alarmins are passively released from necrotic cells upon infection and tissue injury or rapidly secreted by stimulated leukocytes. Alarmins play important intracellular roles in homeostasis and when released extracellularly strongly promote leukocyte cell recruitment and activation as well as tissue repair. This occurs for instance in response to sterile injury or infection [19].

IL-1 $\alpha$ and IL-33 are produced as pro-form but contrary to IL-1 $\beta$, these precursors are already active. Upon cell necrosis, the released IL- $1 \alpha$, IL-33 and HMGB1 alarmins alone or complexed to other molecules bind their respective receptors (IL-1R1, ST2 and RAGE, TLR2 or TLR4) and promote pro-inflammatory gene transcription via the NFkb pathway [16]. We thus hypothesized that lung injury induced by toxic particles leads to the release of intracellular alarmins which can induce pro-IL-1 $\beta$ production and subsequent inflammatory processes.

In this study, we identified the initial events leading to the lung inflammatory response to inhaled particles and found that the constitutively available alarmin IL- $1 \alpha$ is rapidly released in alveolar space in response to silica exposure, before IL-1 $\beta$ induction and pulmonary neutrophil influx. We demonstrated that IL- $1 \alpha$ can directly induce pro-IL-1 $\beta$ production by alveolar macrophages and that its neutralization impairs silica-induced lung IL-1 $\beta$ release and inflammation. Finally, we identified macrophages as a main source of IL-1 $\alpha$ in the lung and developed an in vitro assay to evaluate the inflammogenic activity of nano- and micrometric particles based on their capacity to release IL-1 $\alpha$ from macrophages.

\section{Results}

The early release of the endogenous IL-1 $\alpha$ and IL-33 alarmins precedes silica-induced IL- $1 \beta$ production and neutrophilic inflammation in mice

In order to explore the implication of alarmins in particle-induced IL-1 $\beta$ production in the lung, we first measured in broncho-alveolar lavage fluid (BALF) and lung tissue the protein and gene expression of IL-1 $\alpha$, IL33 and HMGB1 at different time points after an inflammatory dose of micrometric crystalline silica (DQ12, $2.5 \mathrm{mg}$ ) [20,21]. One hour after silica administration, IL$1 \alpha$ and IL-33 protein levels were already significantly increased in BALF. This release peaked at 6 and 12 hours and progressively returned to control values at 24 hours (Figure 1a and b). Silica did not affect BALF HMGB1 levels (Additional file 1: Figure S1a). An increase of lung IL-1 $\alpha$, IL-33 and HMGB1 transcript contents was only observed from 6 hours after silica administration and this effect was maintained up to 24 hours (Additional file 1: Figure S1d, e and f). These data suggest that preexisting stocks of IL-1 $\alpha$ and IL-33 protein are rapidly released in the lung after silica.

The early lung release ( $1 \mathrm{~h})$ of IL- $1 \alpha$ and IL-33 after silica preceded the increased expression of pro-IL-1 $\beta$ and the release of mature IL-1 $\beta$. Indeed, the levels of lung IL-1 $\beta$ transcripts (Figure 1c) and BALF IL-1 $\beta$ protein (Additional file 1: Figure S1b) were mainly increased between 6 and 24 hours following instillation. Cellular lung inflammation was first monitored by BAL total cell and neutrophil (GR1+ cells) counts. Neutrophil accumulation was also quantified by assessing lung expression of CXCR2. Although the expression of this chemokine receptor has been reported in macrophages, CXCR2 is mainly expressed by recruited neutrophils and can be used as a biomarker of neutrophilic inflammation [22]. Akin biochemical parameters (Additional file 1: Figure S1c), cellular inflammation was obvious 6 hours after silica and persisted until 24 hours (Figure $1 \mathrm{~d}$ to $\mathrm{f}$ ). These data suggested that the rapid release of the intracellular stocks of IL- $1 \alpha$ and IL-33 contributes to IL-1 $\beta$ production and neutrophilic inflammation following silica exposure.

\section{The alarmin IL-1 $\alpha$ induces pro-IL-1 $\beta$ production in alveolar macrophages}

We next tested whether the alarmins IL- $1 \alpha$ and IL-33 can directly activate the in vitro expression of pro-IL-1 $\beta$. First, we determined the main cellular source of IL-1 $\beta$ in the lung of mice following silica exposure. IL- $1 \beta$ production is well defined in immune cells but other sources such as epithelial cells have been recently identified $[23,24]$. Therefore, we purified structural (epithelial cells and fibroblasts) and immune cells (i.e. T and B lymphocytes, dendritic cells and macrophages) from the lung of silica-treated mice and measured their pro-IL-1 $\beta$ 


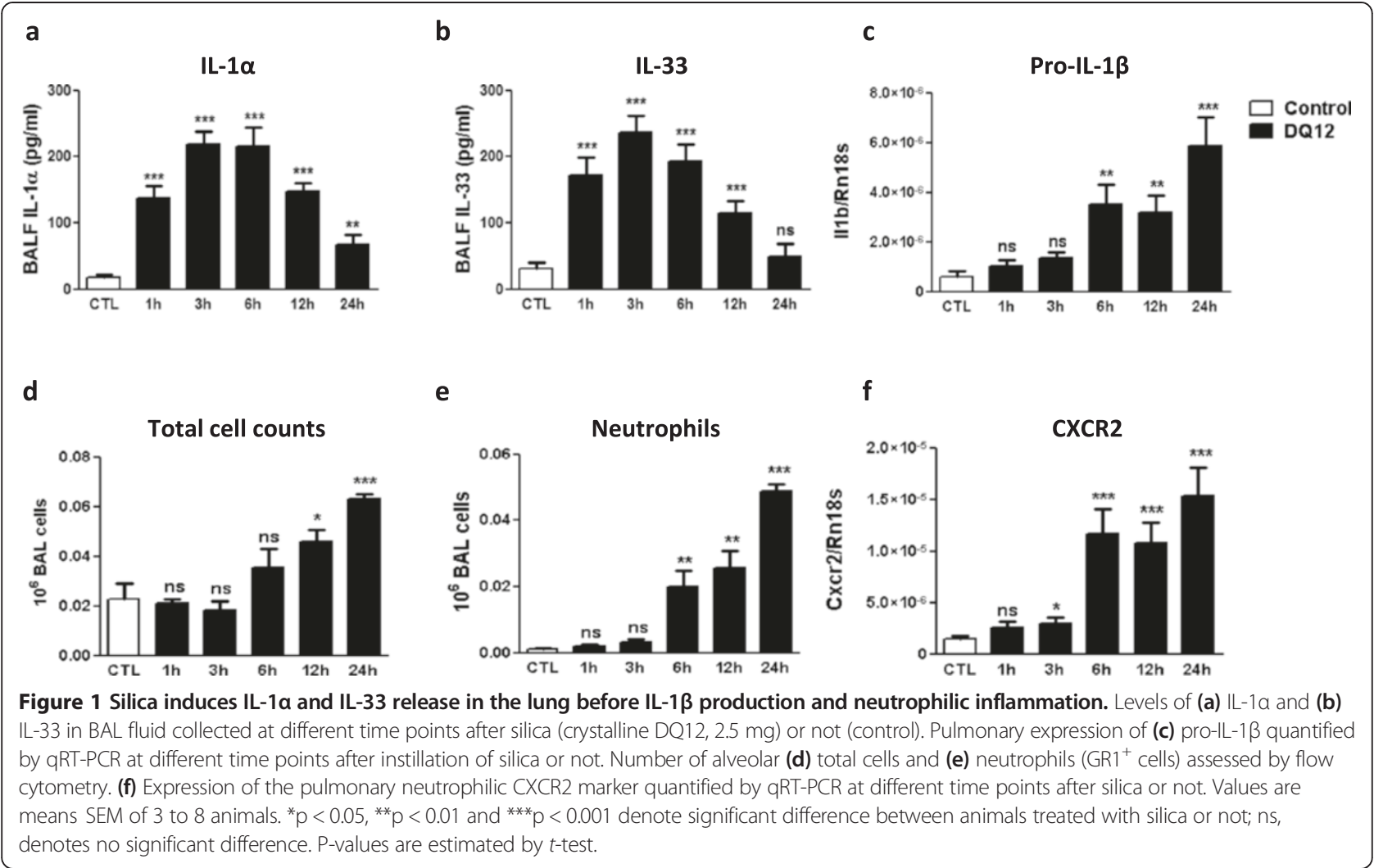

intracellular contents. Lymphocytes and structural cells produced little amount of pro-IL-1 $\beta$ after silica exposure. Alveolar macrophages and dendritic cells produced high levels of pro-IL-1 $\beta$ and were the major cell populations expressing IL-1 $\beta$ in silica treated mice (Figure $2 \mathrm{a}$ ). We also verified that silica alone did not immediately stimulate pro-IL-1 $\beta$ synthesis in primary lung macrophage cultures (Figure $2 \mathrm{~b}$ ). Interestingly, recombinant IL-1 $\alpha$ induced a dose-dependent pro-IL-1 $\beta$ production by alveolar macrophages as appreciated by ELISA (Figure 2c) and western blot analysis (Figure 2d). After recombinant IL-33 addition, a slight but not dose-dependent increase of pro-IL-1 $\beta$ levels was observed by ELISA (Figure 2e) but not by WB analysis (Figure 2f). As expected, the addition of recombinant mature IL-1 $\beta$ in macrophage cultures dose-dependently induced the expression of its pro-form (Figure 2g). At the same concentration, recombinant IL- $1 \alpha$ and IL- $1 \beta$ but not IL-33 induced similar production of pro-IL-1 $\beta$ by alveolar macrophages (Figure $2 \mathrm{~h}$ ). Several forms of recombinant HMGB1 $[25,26]$ had no effect on pro-IL$1 \beta$ expression when added to macrophages (data not shown). Altogether, these results indicated that the alarmin IL- $1 \alpha$ and mature IL- $1 \beta$ strongly stimulate pro-IL$1 \beta$ production by alveolar macrophages.
The alarmin IL-1 $\alpha$ is necessary for IL-1 $\beta$ production in response to silica particles in the mouse lung Because IL- $1 \alpha$ release preceded the expression of IL- $1 \beta$ in silica-treated mice (Figure 1a and c), we then delineated the implication of IL- $1 \alpha$ on silica-induced proIL-1 $\beta$ production and mature IL- $1 \beta$ release by examining the secretion of IL-1 $\beta$ after silica treatment in mice lacking IL- $1 \alpha$. The genetic absence of IL- $1 \alpha$ abrogated proand mature IL-1 $\beta$ expression (Figure $3 a$ and $b$ ) in response to silica. Injection of neutralizing antibodies directed against IL- $1 \alpha[27,28]$ also markedly decreased the levels of IL-1 $\beta$ transcript (Figure 3c) and protein (Figure 3d) in response to silica. These data strongly indicated that the rapid release of IL- $1 \alpha$ promotes IL-1 $\beta$ production in the lung of silica-treated mice.

The alarmin IL-1a contributes to neutrophilic inflammation in response to silica particles in the lung of mice

We next determined the role of IL- $1 \alpha$ in the development of lung inflammation induced by silica by examining neutrophil accumulation. First, we confirmed the pivotal role of IL-1 $\beta$ in lung inflammation development since neutrophil influx after silica was significantly impaired after IL-1 $\beta$ inactivation (KO and blocking antibodies, Figure $4 \mathrm{a}-\mathrm{f}$ ). Genetic deletion of Il1a resulted in 


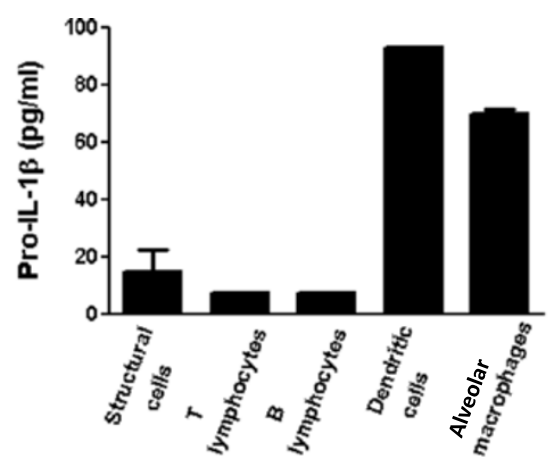

C

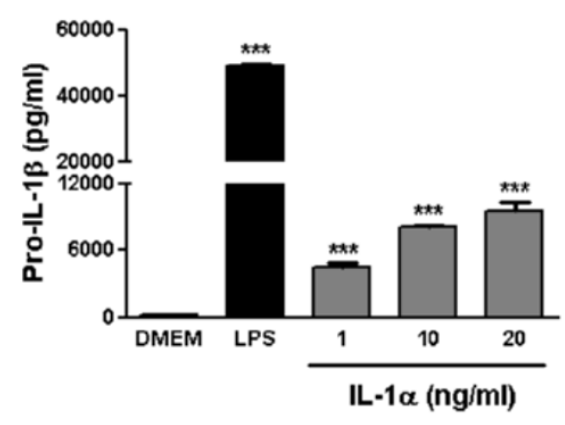

e

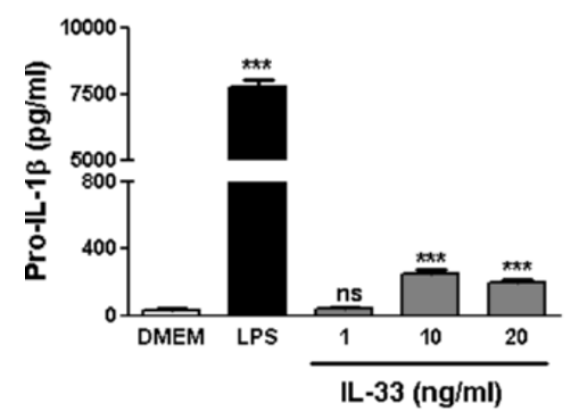

g

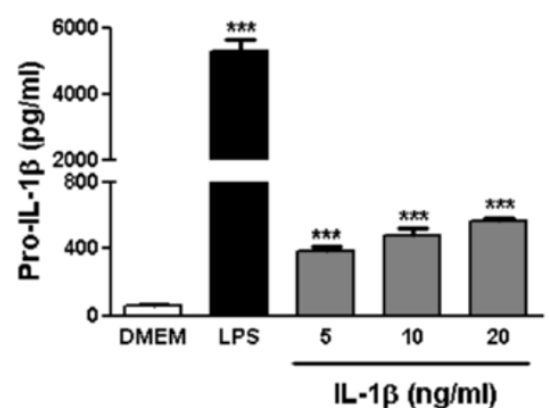

b

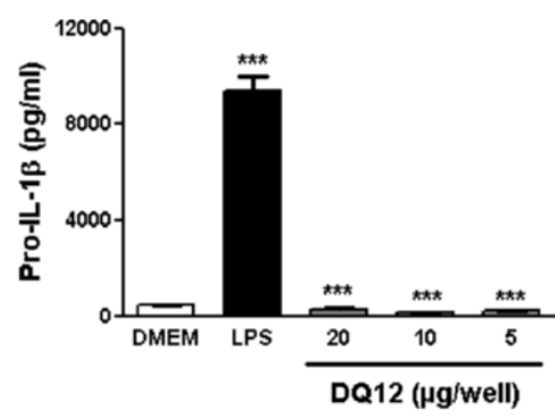

d

$\beta$-actin, 42 kD pro-IL-1 $\beta, 37$ kD

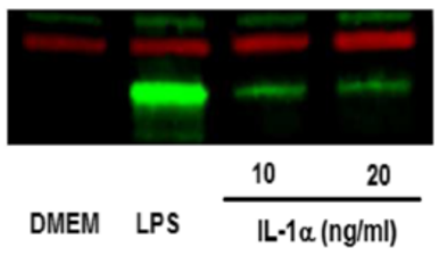

f $\beta$-actin, $42 \mathrm{kD}$ pro-IL-1 $\beta, 37$ kD

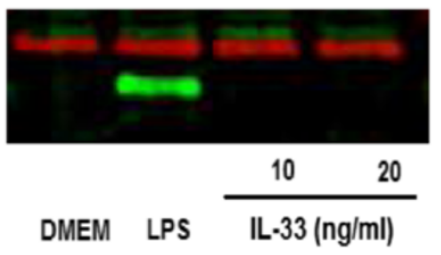

h

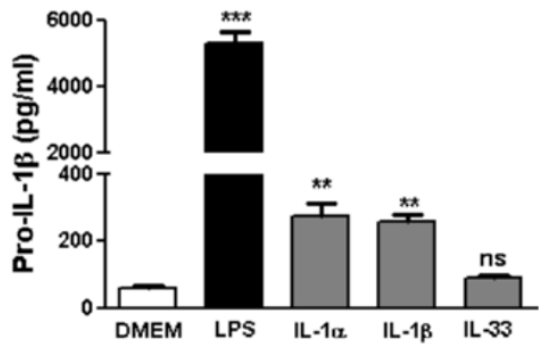

Figure $\mathbf{2}$ (See legend on next page.) 
(See figure on previous page.)

Figure 2 IL-1-induced pro-IL-1 $\beta$ production in alveolar macrophages. (a) Intracellular levels of pro-IL-1 $\beta$ in structural cells (CD45 cells), T

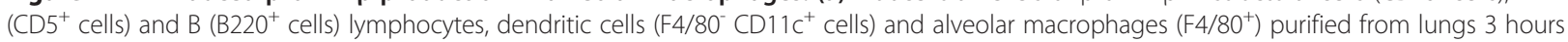
after silica instillation (crystalline DQ12, $2.5 \mathrm{mg}$ ). $\mathrm{n}=2$ to 6 . (b) Intracellular levels of pro-IL-1 $\beta$ in primary cultured alveolar macrophages exposed overnight to LPS $(0.1 \mu \mathrm{g} / \mathrm{ml})$ or silica (DQ12). $\mathrm{n}=4$. Intracellular levels of pro-IL-1 $\beta$ in primary cultured lung macrophages exposed overnight to LPS $(0.1 \mu \mathrm{g} / \mathrm{ml})$ or recombinant IL-1a, IL-33 or IL-1 $\beta$ in different experiments ((c), (e) and (g) respectively) or in the same experiment (10 $\mathrm{ng} / \mathrm{ml})$ (h). $n=3$ to 5 . Western blot analysis of intracellular pro-IL-1 $\beta$ and $\beta$-actin in primary cultured alveolar macrophages exposed during 18 hours to LPS $(0.1 \mu \mathrm{g} / \mathrm{ml})$, (d) recombinant IL-1a or (f) IL-33. Values are means SEM. ${ }^{* *} \mathrm{p}<0.01$ and ${ }^{* * *} \mathrm{p}<0.001$ denotes significant difference between cells in DMEM and cells exposed to LPS, silica, recombinant IL-1a, recombinant IL-33 or recombinant IL-1 $\beta$; ns, denotes no significant difference. P-values are estimated by $t$-test.

a deeper and more complete inhibition of cellular inflammation as appreciated by inflammatory cell and neutrophil accumulation (Figure 4a and b), CXCR2 expression (Figure 4c) as well as histological analyses (Figure 4f). Antibody inactivation confirmed the major implication of IL-1 $\alpha$ in silica-induced neutrophilic inflammation (Figure 4d-f). Altogether, these data indicated that the alarmin IL- $1 \alpha$ indirectly promotes particle-induced lung inflammation through the induction of IL- $1 \beta$ production but also possesses a direct inflammatory activity.

The in vitro release of IL-1a by macrophages upon particle exposure predicts the in vivo inflammatory activity of the particles

In vivo, IL-1 $\alpha$ release upon silica exposure was strongly associated with the subsequent lung inflammatory response.
We thus wondered whether the capacity of particles to induce IL- $1 \alpha$ cell release determines their inflammatory activity and whether it can be used in vitro to predict their toxicity. To test this hypothesis, we first determined the cellular source of the alarmin IL-1 $\alpha$ and assessed in vivo and in vitro its release in response to particles. Intracellular IL- $1 \alpha$ content was measured in different structural and immune lung cell populations from nave or silica-treated mice. Among pulmonary resident cells, only macrophages contained significant amounts of IL- $1 \alpha$ in control animals (Figure 5a). After silica treatment, alveolar macrophages contained and released high amount of IL- $1 \alpha$ (Figure $5 b$ and c). To a lesser extent, dendritic cells and B lymphocytes also produced and released IL- $1 \alpha$ after silica instillation. Moreover, freshly purified alveolar macrophages from nave mice released IL- $1 \alpha$ in the medium in response a

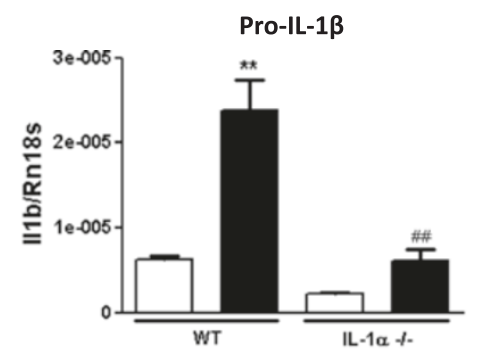

c

Pro-IL-1 $\beta$

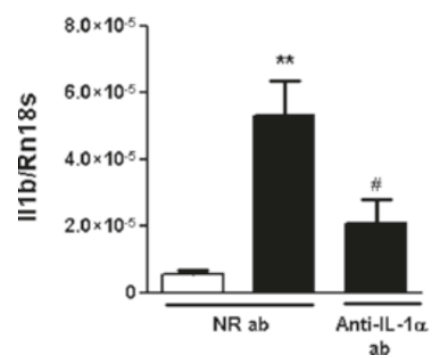

b

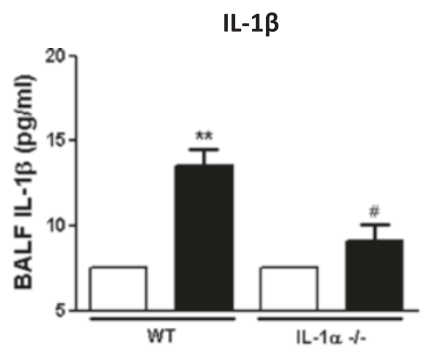

d

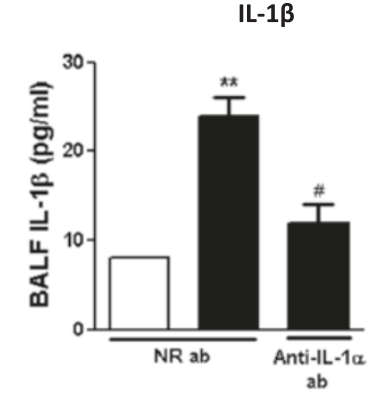

Figure 3 IL-1 1 inhibition reduces IL-1 $\beta$ production in lung of silica-treated mice. (a) Pulmonary expression of pro-IL-1 $1 \beta$ quantified by qRT-PCR and (b) levels of mature IL-1 $\beta$ in BAL fluid of WT and IL-1a KO mice, 24 hours after instillation of silica (crystalline DQ12, 2.5 mg) or not (control). (c) Pulmonary expression of pro-IL-1 $\beta$ quantified by qRT-PCR and (d) levels of mature IL-1 $\beta$ in BAL fluid 18 hours after silica or not, in mice treated with IL-1a neutralizing antibody or not. Values are means SEM of 3 to 8 animals. ${ }^{* *} p<0.01$ denote significant difference between animals treated or not with silica. \# $p<0.05$, \#\# $p<0.01$ denote significant difference between silica-treated animals with decreased or unmodified IL-1a. P-values are estimated by t-test. 


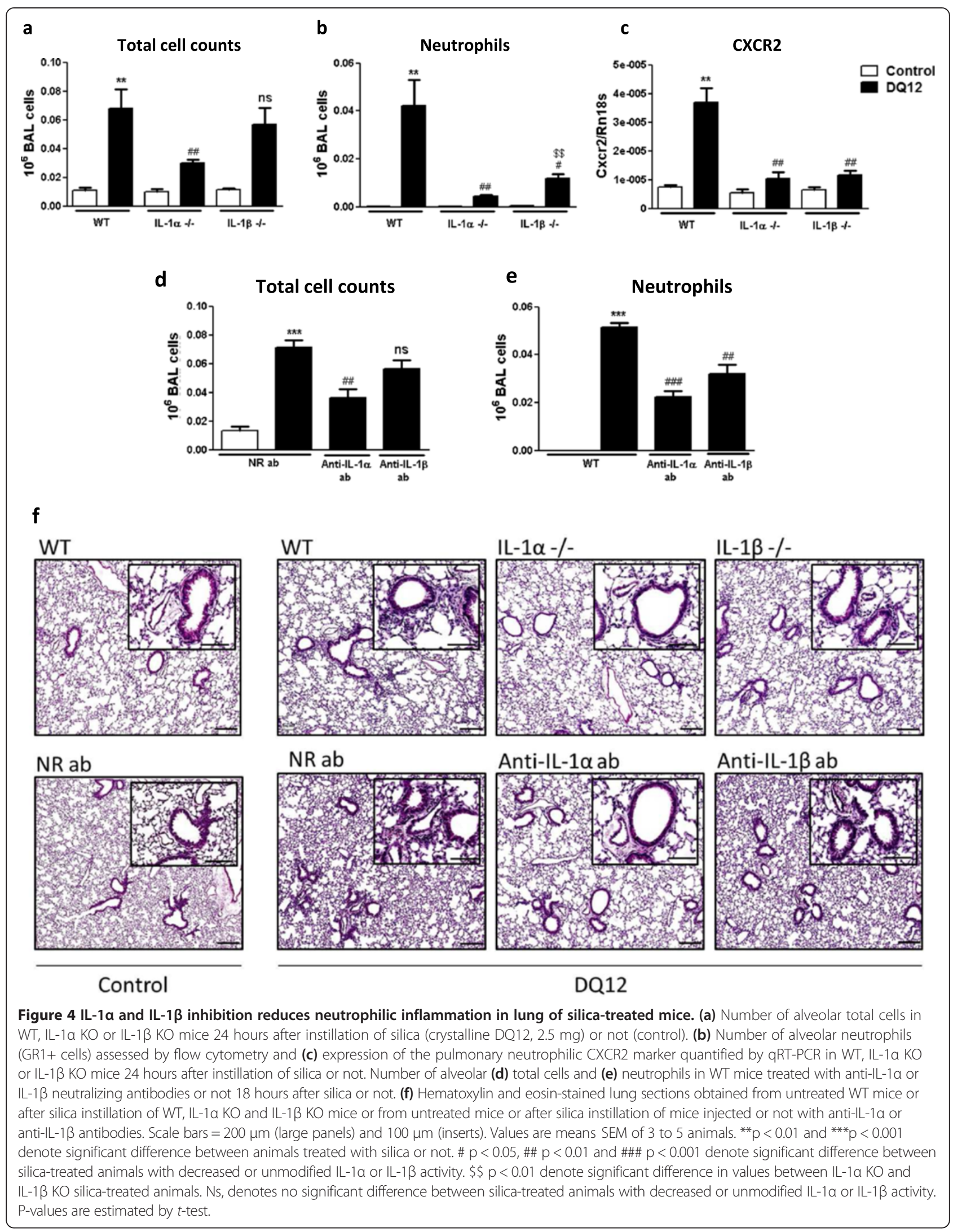




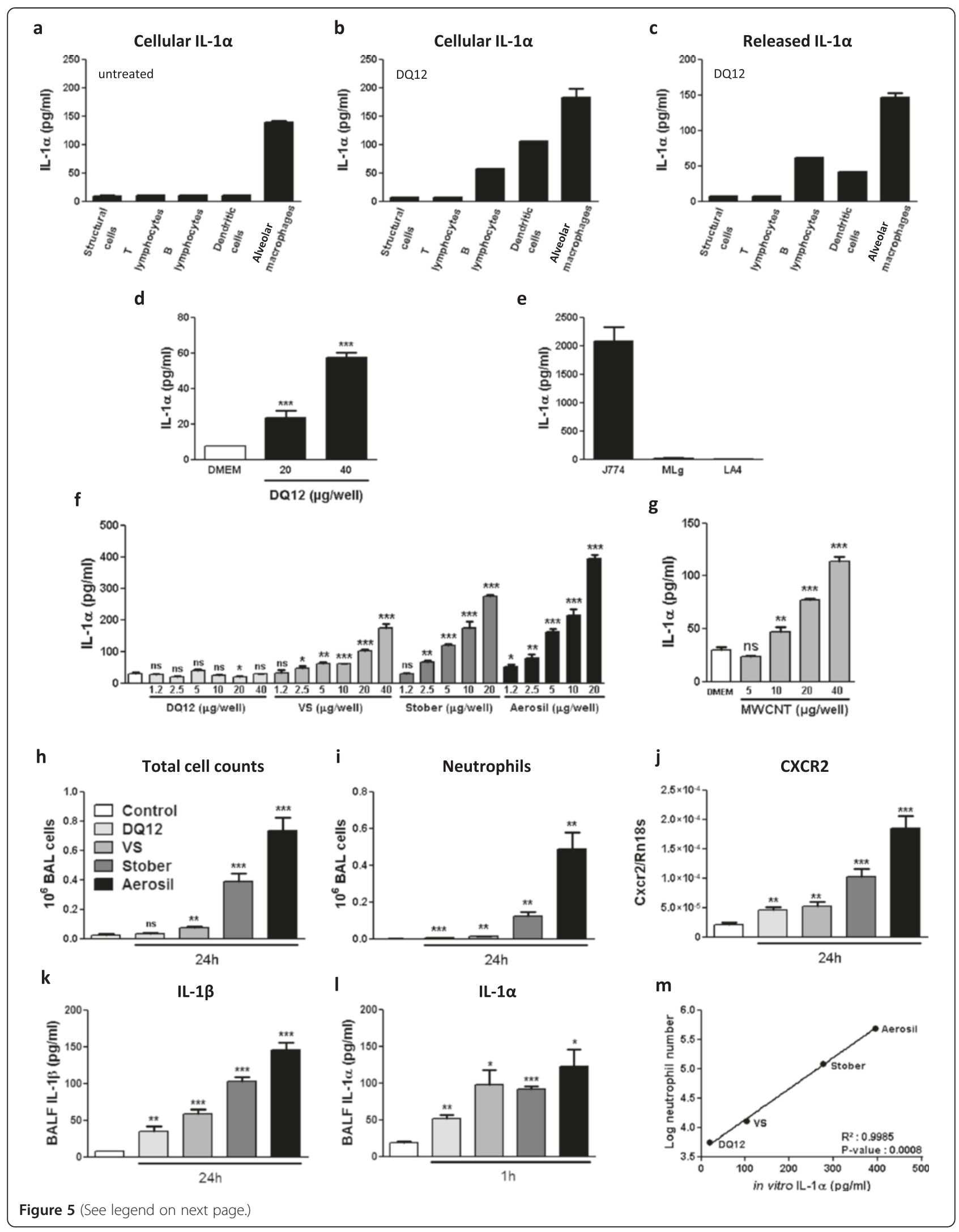


(See figure on previous page.)

Figure $5 \mathrm{IL}-1$ a release by $\mathbf{J 7 7 4}$ macrophages after particle exposure predicts acute lung inflammation upon particle treatment in mice. Intracellular levels of IL-1a in structural cells (CD45 cells), T (CD5 ${ }^{+}$cells) and B (B220+ cells) lymphocytes, dendritic cells (F4/80- CD11 $\mathrm{C}^{+}$cells) and alveolar macrophages $\left(\mathrm{F} 4 / 80^{+}\right)$freshly purified from (a) untreated lung or (b) 3 hours after silica instillation (crystaline DQ12, $2.5 \mathrm{mg}$ ). $\mathrm{n}=1$ to 6 . (c) Release of IL-1a by structural cells (CD45 cells), T (CD5 ${ }^{+}$cells) and B (B220+ cells) lymphocytes, dendritic cells (F4/80- CD11 ${ }^{+}$cells) and alveolar macrophages $\left(\mathrm{F} 4 / 80^{+}\right)$purified from lungs 3 hours after silica instillation. $n=1$ to 6 (d) Release of IL-1a by fresh primary lung macrophages (CD45 ${ }^{+} \mathrm{F} 4 /$ $80^{+}$) exposed to silica (overnight). $n=4$. (e) Intracellular levels of IL-1a in macrophage (J774), fibroblast (MLg) and epithelial (LA4) cell line. $n=2$ to 6. (f) Release of IL-1a by $\mathbf{J 7 7 4}$ exposed overnight to increasing concentration of DQ12, Vitreous Silica (VS), Stber silica nanoparticles (Stober) and Aerosil 200. $n=3$ to 4 . (g) Release of IL-1a by $J 774$ exposed overnight to various concentration of MWCNT. $n=3$ to 4 . (h) Number of alveolar total cells 24 hours after particle instillation $\left(1.2 \mathrm{mg}\right.$ ) or not. (i) Number of alveolar neutrophils (GR1 ${ }^{+}$cells) assessed by flow cytometry and (j) expression of the pulmonary neutrophilic marker CXCR2 quantified by qRT-PCR in mice 24 hours after particle instillation or not. Levels of (k) mature IL-1 $\beta$ or (I) IL-1a in BAL fluid collected respectively 24 hours or 1 hour after instillation of particles or not. $(\mathbf{m})$ Correlation between alveolar neutrophils (log GR $1^{+}$cells) collected 24 hours after particle instillation and levels of IL-1a in supernatant of particle-exposed J774. Values are means SEM of 3 to 6 animals. ${ }^{*} p<0.05$,

${ }^{* *} p<0.01$ and ${ }^{* *} p<0.001$ denote significant difference between particle-treated and not animals; ns, denotes no significant difference. P-values are estimated by $t$-test. Correlation is calculated based on Pearson coefficient.

to silica exposure (Figure $5 \mathrm{~d}$ ). These data indicated that alveolar macrophages represent the main IL-1 $\alpha$-secreting lung cells and can be used to assess the alarmin IL- $1 \alpha$ release in response to silica in vitro.

In order to develop an in vitro screening test, we next assessed the intracellular IL- $1 \alpha$ content in murine macrophage (J774), fibroblast (MLg) and epithelial (LA-4) cell lines. Results on cell lines confirmed observations made on primary lung cells, i.e. that macrophages possess high constitutive IL- $1 \alpha$ content, contrary to fibroblastic and epithelial cells (Figure 5e). We then compared IL- $1 \alpha$ released by J774 in response to increasing amounts of different silica particles: micrometric crystalline silica (DQ12), micrometric amorphous silica (Vitreous Silica; VS), and two different amorphous nanosilica (Stber and Aerosil 200) (Figure 5f). While DQ12 silica induced a slight release of IL- $1 \alpha$ in J774 macrophage supernatant, vitreous and Stber silica induced a significant IL-1 $\alpha$ release from $2.5 \mu \mathrm{g}$ of particle per well, while Stber-induced IL-1 $\alpha$ release was higher. Finally, Aerosil 200 already induced a significant increase of IL- $1 \alpha$ levels at the dose of $1.2 \mu \mathrm{g} /$ well. Based on these data, we concluded that the tested silica particles induce IL- $1 \alpha$ release by J774 macrophages in the following order: DQ12 < VS < Stber < Aerosil 200. In parallel, mice were instilled with $1.2 \mathrm{mg}$ of the 4 silica particles and lung IL- $1 \alpha$ release, neutrophilic accumulation and IL-1 $\beta$ expression were evaluated. IL- $1 \alpha$ concentrations assessed in BALF 1 hour after particle instillation were increased as in vitro: DQ12 induced a limited release of IL-1 $\alpha$, VS and Stber were associated with a moderate release of IL- $1 \alpha$ while Aerosil induced the strongest IL- $1 \alpha$ release (Figure 5l). Particle-induced inflammatory and neutrophilic accumulation (Figure $5 \mathrm{~h}-\mathrm{j}$ ) and IL-1 $\beta$ production (Figure $5 \mathrm{k}$ ) also correlated to in vitro IL-1 $\alpha$ release. Correlation analyses between in vitro IL- $1 \alpha$ release $(20 \mu \mathrm{g}$ of particle/well) and in vivo neutrophilic accumulation induced by the different silica particles confirmed the clear association between the in vivo lung inflammation intensity and the IL- $1 \alpha$ release (Figure $5 \mathrm{~m}, \mathrm{R}^{2}=0.9985$, p-value 0.0008). MWCNT, known for their lung inflammatory potential [29], also induced IL-1 $\alpha$ release from macrophages (Figure 5g). In conclusion, IL-1 $\alpha$ release by J774 macrophages was predictive of the acute lung inflammation consecutive to silica particle exposure.

\section{Discussion}

Recent evidence demonstrated that NLRP3 inflammasome activation by particles is pivotal in the release of the pro-inflammatory cytokine IL-1 $\beta$ and the development of lung inflammation $[4,7,11]$. Particles such as silica activate the inflammasome platform through potassium-, cathepsin- and/or ROS-dependent pathways and allow the release of the cleaved and active IL-1 $\beta$. The early events leading to pro-IL-1 $\beta$ production following exposure to particles are, however, not identified yet. In models of sterile inflammation, damaged and necrotic cells release intracellular stores of biologically active alarmins that initiate subsequent pro-inflammatory cytokine transcription and neutrophil recruitment [30,31]. We thus postulated that early alarmin release due to particle-induced cell damage can induce pro-IL-1 $\beta$ production and subsequent inflammatory reaction. We discovered that IL- $1 \alpha$ and IL-33 were released in response to particle instillation from preexisting cellular stocks. To our knowledge, this is the first time that early release of these alarmins is evaluated in the genesis of inflammation induced by inorganic particles.

Once in the extracellular environment, IL-1 $\beta$ and IL$1 \alpha$ both bind to the IL-1R1/IL-1rAcP complex and induce similar effects. However, contrary to IL- $1 \beta$, IL- $1 \alpha$ does not require maturation and/or exocytosis to be active; its precursors form can activate IL-1R1 or translocate to the nucleus where it will modify inflammatory gene transcription [32]. The role of the IL-1 family in particle-induced neutrophilic inflammation has been extensively investigated mainly by using IL-1 signaling pathway inhibition $[3,11]$ i.e. IL-1Ra (IL-1receptor antagonist) administration [33] or inflammasome activation 
impairment $[3,7,34]$. Due to their functional redundancy, these studies do not allow to discriminate between IL-1 $\alpha$ or IL-1 $\beta$ implication. Some reports specifically demonstrated a tempering effect of IL-1 $\beta$ deficiency on particle-induced inflammation $[4,5,35,36]$. A dominant role of IL- $1 \alpha$ compared to $\mathrm{IL}-1 \beta$ has been demonstrated in nano-TiO2-induced peritonitis and lung neutrophilic inflammation by using IL$1 \mathrm{R}$-, IL-1 $\alpha$ - or inflammasome component-deficient mice [23]. In the present study, we newly demonstrate the implication of IL- $1 \alpha$ in pro-IL-1 $\beta$ production consecutive to particle exposure. Indeed, IL-1 $\alpha$ stimulated precursor IL-1 $\beta$ production by macrophages and the absence of this alarmin abrogated mature IL-1 $\beta$ release upon silica treatment in mice. This is in accordance with observations of Gross and co-authors who reported that absence of IL-1 $\alpha$ reduced IL$1 \beta$ levels measured in response to monosodium urate (MSU) intraperitoneal injection [5]. Similarly, IL-1 $\alpha$ neutralizing antibodies decreased lung IL-1 $\beta$ induction due to cigarette smoke [37]. The effect of IL-1 $\alpha$ on IL-1 $\beta$ induction was also directly observed on macrophages in vitro $[5,15,32,38-40]$. Interestingly, the implication of IL- $1 \alpha$ as a dominant IL-1 cytokine has also been recorded in other murine models of toxic lung inflammation or peritonitis. Alveolar and peritoneal neutrophilic accumulation induced by bleomycin, cigarette smoke or MSU were reduced when IL- $1 \alpha$ response was inhibited $[5,27,37,41]$.

IL- $1 \alpha$ is a constitutive and ubiquitary cytokine (reviewed in [32]) whose release is frequently assessed in epithelial cells $[41,42]$ or macrophages $[15,43,44]$. In this paper, we established that among lung resident cells, macrophages represent a major source of available IL- $1 \alpha$. We also demonstrated their ability to release IL- $1 \alpha$ in response to particle exposure. Resident macrophages have already been implicated in IL-1 $\alpha$ release under inflammatory conditions in lung [37], but also in liver [45] and brain [46]. It has been recently shown that particles-induced pyroptosis, a lytic mode of cell death that exhibits cytoplasmic swelling and ruptures of the plasma membrane [47]. It is tempting to postulate that pyroptosis results in the release of IL-1 $\alpha$ by dying macrophages. In addition, it is surprising to note that the release of IL- $1 \alpha$ by alveolar macrophages exposed in vitro to silica particles does not result in a direct production of pro-IL-1 $\beta$. IL-1 $\alpha$-releasing macrophages are dying cells and thus probably unable to newly produce pro-IL-1 $\beta$. In vivo, extracellular IL- $1 \alpha$ from necrotic macrophages could, however, trigger pro-IL-1 $\beta$ production by surrounding active macrophages which then propagate neutrophilic inflammation by processing IL- $1 \beta$ after silica endocytosis. Finally, amorphous silica particles are generally regarded as less harmful than the crystalline forms [48-50]. We showed that amorphous (nano)silica particles induced stronger IL-1 $\alpha$ secretion and inflammation than crystalline particles. These observations are in line with the recent conclusions offered by several experimental studies indicating that some amorphous (nano)silica particles need to be considered as potent toxic entities [51-55].

We evidenced that IL-33 is released in the lung upon particle instillation. This alarmin did, however, not participate significantly in IL-1 $\beta$ production by lung cells. We also observed a strong induction of IL-33 mRNA 24 hours after silica instillation, suggesting a possible implication in later inflammatory processes. Indeed, recent studies have shown that IL-33 is released in response to particle administration [56,57] and is implicated in lung inflammation after 30 days [58-60].

As observed after cristobalite or asbestos exposure $[24,33]$, it has been recently found that the alarmin HMGB1 was released in alveolar space after MWCNT treatment in mice [61]. The secreted HMGB1 enhanced IL-1 $\beta$ release from alveolar macrophages and its neutralization reduced lung IL-1 $\beta$ content and inflammation in vivo [61]. In contrast, we did not observe an increase of HMGB1 alveolar levels in response to silica and different recombinant forms of HMGB1 did not stimulate IL- $1 \beta$ production by alveolar macrophages in vitro. This apparent discrepancy could be explained by the type of pulmonary cells targeted by the particles. MWCNT may cause strong cell damage to epithelial cells while silica may preferentially affect macrophages. This could result in the activation of different endogenous danger signal and inflammatory pathways, i.e. related to HMGB1 or IL-1 $\alpha$, respectively. Importantly, Jessop and colleagues demonstrated that HMGB1 present in BAL fluid of MWNCT-treated mice induced IL-1 $\beta$ release by macrophages while recombinant failed. This suggest that the complexation with other inflammatory molecules [62] or the redox status of HMGB1 [25] are mandatory for HMGB1 inflammatory activity. These modifications may also prevent HMGB1 recognition by the ELISA assays and interfere with HMGB1 detection after particle treatment.

The activation of the NFkB pathway leading to il- $1 \mathrm{~b}$ gene expression is probably not limited to IL- $1 \alpha$. Indeed, the pro-inflammatory cytokine TNF- $\alpha$ is also known to induce NFkB activation and IL-1 $\beta$ production $[33,63]$. Also this cytokine can be released rapidly and independently of transcriptional induction [64]. It is well known that TNF- $\alpha$ is a key factor in the development of lung inflammation upon particle exposure [33,65-67]. As for IL- $1 \alpha$, we showed that TNF- $\alpha$ induced the production of pro-IL-1 $\beta$ in primary lung macrophages in vitro (Additional file 1: Figure 2), suggesting that a pleiad of pro-inflammatory mediators may indirectly amplify the production of immature IL-1 $\beta$. Additional investigations are also needed to better delineate the role the alarmin S100 and heat shock proteins highly secreted following particle exposure [68-70].

Increased levels of IL-1 cytokines were reported in patients suffering from particle-associated inflammatory diseases such as asbestosis [71] and silicosis [72-74]. 
Targeting IL-1 $\beta$, e.g. through the use of Anakinra (a recombinant non-glycosylated version of human IL-1Ra) is already in use for the clinical treatment of gout and other IL-1 $\beta$-related autoimmune diseases [75]. Interestingly, the interaction of Anakinra with the IL-1 receptor prevents the biological functions of IL-1 $\beta$ but also of IL-1 $\alpha$. Our data extend this therapeutic possibility in particle-induced lung inflammation by showing that blocking the IL-1 $\alpha / \beta$ pathway significantly reduces the deleterious influx of neutrophils after particle exposure. It remains, however, to demonstrate whether IL-1 blockade could also be associated with a reduction of particleinduced lung fibrosis [48]. Indeed, we recently showed that mice lacking IL-1 $\beta$, IL- $1 \alpha$ or IL-1R and treated with DQ12 silica presented a reduction of chronic lung inflammation and granuloma formation compared to their WT counterparts. However, this strong effect on inflammatory development was not concomitantly accompanied by a reduction of lung fibrosis, suggesting that inhibiting IL-1-driven inflammation may not be sufficient to control the fibrotic lung disease after particle exposure [76].

Finally, we showed that IL- $1 \alpha$ release by the macrophage J774 cell line is highly predictive of the acute inflammogenic potential of silica micro- and nanoparticles. These results are in agreement with other studies that demonstrated the predictive value of IL- $1 \alpha$ release to screen the skin irritative potential of various chemicals [77-80]. Hence, the in vivo inflammatory response to silica can be predicted by a simple and quantitative model based on in vitro release of IL- $1 \alpha$ by cell line macrophages. This model may serve in (nano)toxicology to predict the in vivo toxicity of new materials and particles and to reduce animal uses.

\section{Conclusion}

The present study clarifies the respective role of IL- $1 \alpha$ and $\beta$ in particle-induced lung inflammation. We found that the release of endogenous IL- $1 \alpha$ represents an early and crucial event that determines lung inflammatory responses to particle in mice (Figure 6). Released IL-1 $\alpha$ after particle exposure serves as an alarmin that triggers the expression and the secretion of IL-1 $\beta$. Alveolar macrophages represent the major source of IL- $1 \alpha$ and IL- $1 \beta$ and macrophage population can be used to develop in vitro assays useful for screening the acute inflammatory potential of various types of particles. Finally, our results emphasize the need to target both IL- $1 \alpha$ and IL- $1 \beta$ for regulating particleassociated lung inflammatory diseases.

\section{Materials and methods Particles}

Crystalline silica particles (DQ12; DMT GmbH and Co. KG, Essen, Germany), Vitreous silica (VS; a gift from Dr.
Ghiazza, University of Torino, Italy), Aerosil 200 (SigmaAldrich, Bornem, Belgium) and multi-wall carbon nanotubes (MWCNT; MWNT-7, Mitsui, Tokyo, Japan) powders were sterilized by heating at 200c for $2 \mathrm{~h}$ immediately before suspension. Sterile Stber particle suspension were synthesized based on Stber process and its characterization was described elsewhere [81]. Characteristics of the particles are listed in Table 1.

\section{Animal model}

Female C57BL/6 mice were obtained from Janvier (Le Genest-Saint-Isle, France). IL-1 $\alpha-$, IL-1 $\beta-$, IL1-R1- and MyD88-competent and -deficient mice (in C57BL/6 background) were obtained from the Transgnose Institute (Orleans, France). Studies were performed on gender-matched littermates aged 8-12 weeks. The animals were housed in positive pressure air-conditioned units (25C, 50\% relative humidity) on a 12-hr light/dark cycle and had access to standard diet and tap water ad libitum. The experiments were conducted in accordance with the National Research Council Guide for the Care and Use of Laboratory Animals and approved by the institutional Ethics Committee. Suspensions of crystalline DQ12 silica particles in sterile water or $0.9 \%$ saline (Braun Medical, Diegem, Belgium) were injected directly into the lung by pharyngeal aspiration at a dose of $2.5 \mathrm{mg} / \mathrm{mouse}$ inducing robust lung inflammation [20,21]. Anti-IL-1 $\alpha$ antibody (clone AL-161; e-Biosciences, San Diego, USA) and anti-IL-1 $\beta$ antibody (clone B-122; eBiosciences) were injected into the peritoneal cavity at a dose of $80 \mu \mathrm{g} /$ mouse 1 hour before silica instillation [5].

\section{Broncho-alveolar lavage (BAL) and alveolar cell number}

Mice were sacrificed with an intraperitoneal injection of sodium pentobarbital (20 mg/mice) and bronchoalveolar lavage was performed by cannulating the trachea and lavaging the lung 4 with $1 \mathrm{ml}$ of $\mathrm{NaCl} 0.9 \%$. The broncho-alveolar lavage fluid (BALF) was centrifuged at 281g, 10 min, 4C (Centrifuge 5804R, Eppendorf, Hamburg, Germany). Cells recovered in BAL were counted then fixed in $1.25 \%$ paraformaldehyde and analyzed with FACS calibur (BD Biosciences) using FlowJo software. Neutrophils were identified by labelling with anti-GR1-PE (clone RB6-8C5, BD Biosciences, Erembodegem, Belgium) and their number calculated in function of total BAL cells counted with a Burker cell chamber. Fc receptors were blocked with anti-CD16/CD32 (clone 2.4G2, $\mathrm{BD}$ Biosciences) to reduce nonspecific binding.

\section{Lung histopathology}

Lungs were lavaged and perfused with $0.9 \% \mathrm{NaCl}$ and superior left lung lobe was fixed in $3.6 \%$ formaldehyde solution (Sigma-Aldrich) during one night. Paraffinembedded 5- $\mu \mathrm{m}$ sections were stained with hematoxylin 


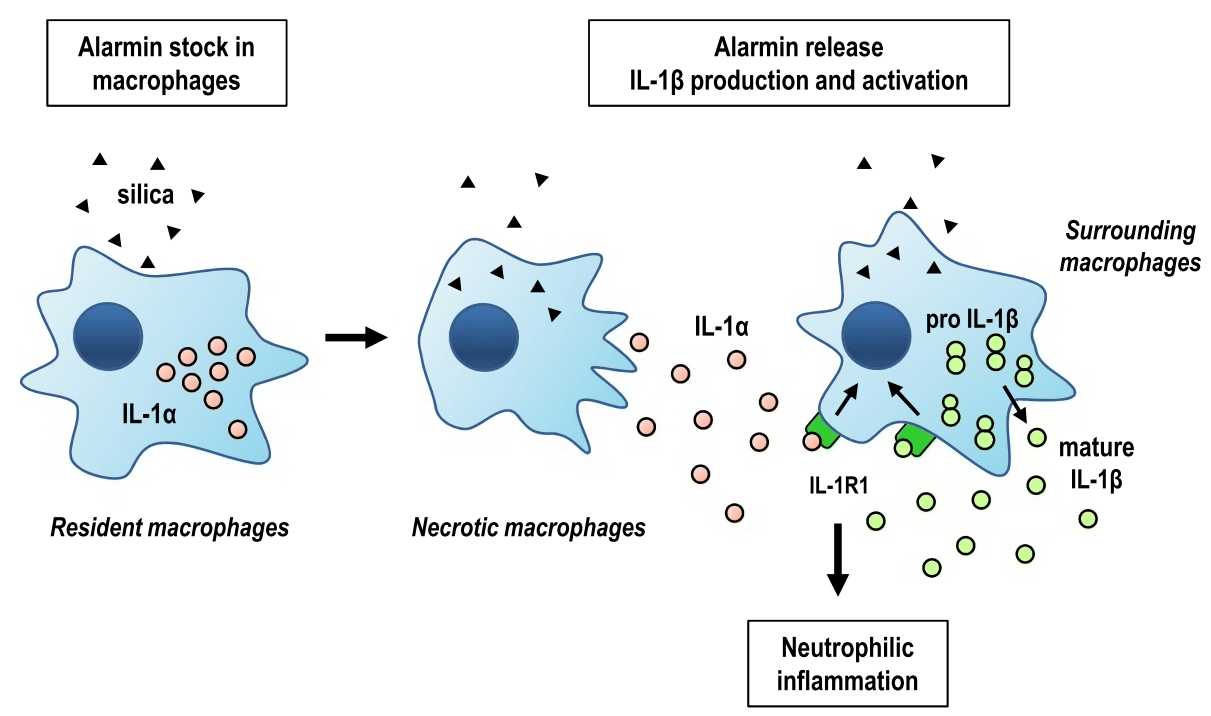

Figure 6 IL-1a released by alveolar macrophages upon particle exposure mediates neutrophilic inflammation directly and via IL-1 $\beta$ production. In homeostasis, IL-1a is constitutively expressed by resident alveolar macrophages and intracellularly retained as preexisting stocks. Released IL-1a into the extracellular milieu by necrotic macrophages serves as alarmin after silica exposure. IL-1a is a potent activating stimulus required for surrounding macrophages to express the biologically inactive precursor IL-1 $\beta$ (pro-IL-1 $\beta$ ). This form is cleaved by silica-induced inflammasome assembly and activation prior its secretion as mature and bioactive IL-1 $\beta$. IL-1a and $\beta$ relayed by their receptor (IL-1R) are necessary to generate pulmonary neutrophil accumulation in response to silica particles.

and eosin. Images were acquired with a slide scanner SCN400 and analyzed with Digital Image Hub (Leica Microsystems, Diegem, BE).

\section{RNA extraction and quantification}

Total RNA extraction and quantification by qRT-PCR were performed as described [86]. Sequences of interest were amplified by PCR using the following forward primers (Invitrogen): CGG CTA CCA CAT CCA AGC AA (mouse Rn18s ), GAC GGA CCC CAA AAG ATG AAG (mouse Il1b), GGA CTT CTC AAG ATC ATG GCT ACT T (mouse Cxcr2), TTG AAG ACC TAA AGA ACT GTT ACA GTG AA (mouse Il1a), GGA AAA GAC CAA GAG CAA GAC C (mouse Il33), TTT TGT CCA CAT GCC CTG C (mouse Hmgb1), and reverse primers: ATA CGC TAT TGG AGC TGG ATT ACC (mouse Rn18s), CTC TTC GTT GAT GTG CTG CTG TG (mouse Illb), TAG TAG AGG TGT TTG CTG AAG ACG A (mouse Cxcr2), GCC ATA GCT TGC ATC ATA GAA GG (mouse Il1a), TTC TTC CCA TCC ACA CCG TC (mouse Il33), CTA ATA GTC CCA CGG TGT GAC AGT (mouse Hmgb1).

\section{Cell purification}

Mice treated with silica $(2,5 \mathrm{mg} /$ mouse $)$ or not were sacrificed after 3 hours by intramuscular injection of 60 mg sodium pentobarbital. Lungs were perfused via the right heart ventricle with sterile $\mathrm{NaCl} 0.9 \%$. One ml of enzyme mix containing $20 \mathrm{mg}$ of pronase (Sigma-Aldrich) and $1 \mathrm{mg}$ of dnase (Worthington Biochemical Corporation,

Table 1 Physicochemical characterization of the particles

\begin{tabular}{|c|c|c|c|c|}
\hline Name & Type & Crystallinity & Size TEM $(\mathrm{nm})$ & Surface BET $\left(\mathrm{m}^{2} / \mathrm{g}\right)$ \\
\hline DQ12 & Ground natural mineral & Crystalline & $960^{a}$ & $7,4-10,1^{b}$ \\
\hline VS & Ground fused silica & Amorphous & $1600^{c}$ & $3.1^{c}$ \\
\hline Stber & Stber silica & Amorphous & $12^{d}$ & $400^{d}$ \\
\hline Aerosil 200 & Fumed silica & Amorphous & $12^{\mathrm{e}}$ & $175-225^{\mathrm{e}}$ \\
\hline \multirow[t]{2}{*}{ MWCNT } & Multi-wall carbon nanotubes & N/a & Length :5,700 3,700 ${ }^{\mathrm{f}}$ & $22^{f}$ \\
\hline & & & Width : $7428^{f}$ & \\
\hline
\end{tabular}

(a) [82].
(b) [83].
(c) [51].
(d) [84].
(e) Data provided by the manufacturer (Sigma-Aldrich).
(f) [85].


Lakewood, USA) in HBSS (Invitrogen; Merelbeke; Belgium) with $1 \%$ of antibiotic antimycotic (AA) (fungizone $(25 \mu \mathrm{g} / \mathrm{mL})$, penicillin streptomycin (10000 U and $10000 \mu \mathrm{g} / \mathrm{mL}$ ); Invitrogen) were infused in cannulated trachea. After 20 minutes, lungs were excised and placed into a tube chilled on ice with fetal bovine serum (FBS) (Invitrogen). Collected lungs were then crushed by repeated aspiration and expulsion in a $20 \mathrm{ml}$ seringue and passed on a $70 \mu \mathrm{M}$ filter. Structural cells were purified based on their absence of CD45 expression by using magnetic cell separation (MACS; Miltenyi Biotec) according to the manufacturer's protocol; $\mathrm{T}$ lymphocytes based on their CD5 expression; B lymphocytes based on their B220 expression; dendritic cells based on their absence of F480 and the presence of CD11c expression; and alveolar macrophages based on their F480 expression. Alveolar macrophages were also obtained from lung cell suspensions grown in $75 \mathrm{~cm}^{2}$ tissue culture flask in DMEM (Invitrogen) supplemented with 10\% FBS and $1 \%$ of AA, detached using trypsin (Invitrogen) and purified based on their CD45 expression by using magnetic cell separation (MACS) according to the manufacturer's protocol.

\section{Pro-IL-1 $\beta$ and IL-1 $a$ content in lung cells}

For ELISA measurement of intracellular or released proIL- $1 \beta$ or IL- $1 \alpha$, fresh lung cells purified from nave or silica treated mice, primary cultured macrophages, J774, MLg or LA4 $\left(10^{6}\right.$ cells/well in 96-well plate) were exposed overnight with LPS $(0,1 \mu \mathrm{g} / \mathrm{ml}$; Enzo Life Sciences, Antwerpen, Belgium), DQ12, mouse recombinant IL- $1 \alpha$, IL-33, IL-1 $\beta$, TNF- $\alpha$ (R\&D systems, Minneapolis, USA) or HMGB1 (chemokine, non-oxydable and cytokine form; HMGBiotech, Milano, Italia) when necessary. For intracellular cytokine measurement, cell pellets were lysed by addition of $100 \mu \mathrm{l}$ of triton X-100 0,1\%. The ex vivo released of IL- $1 \alpha$ were quantified by ELISA in the supernatants of cells purified from silica-treated lungs maintained in culture during 24 hours in $100 \mu \mathrm{l}$ of DMEM. For in vitro IL-1 $\alpha$ release in response to particles, fresh alveolar $\mathrm{F} 4 / 80^{+}$macrophages $\left(10^{6}\right.$ cells/well in 96 -well plate) or J774 cells $\left(0.410^{6}\right.$ cells/well in 96-well plate) were incubated overnight with particles dispersed in $100 \mu \mathrm{l}$ of DMEM and IL- $1 \alpha$ was measured in the supernatant.

For western blot analysis, cells were lysed on ice in $200 \mu \mathrm{l}$ Triton lysis buffer (TLB) (1\% Triton, $25 \mathrm{mM}$ Tris pH 7.4, $150 \mathrm{mM} \mathrm{NaCl}+$ anti-protease tablets from Roche Applied Science at $2 \mathrm{mg} / \mathrm{ml}$ ). Protocol for Western blot is described elsewhere [84].

\section{Enzyme-linked immunosorbent assays (ELISA)}

ELISA kits were used to measure IL-1 $1 \beta$, IL-1 $\alpha$, IL-33 (DY401, R\&D Systems, Wiesbaden-Nordenstadt, Germany), HMGB1 (Cedarlane Laboratories USA Inc., Burlington,
USA) and pro-IL-1 $\beta$ (e-Biosciences). Assays were run according to the manufacturer's protocols with a detection limit of $5 \mathrm{pg} / \mathrm{ml}$ for $\mathrm{IL}-1 \beta$, IL- $1 \alpha$, IL-33, $0,2 \mathrm{ng} / \mathrm{ml}$ for HMGB1 and $25 \mathrm{pg} / \mathrm{ml}$ for pro-IL-1 $\beta$

\section{Statistics}

Results were analyzed by $t$-test. Statistical significance was considered at $\mathrm{P}<0.05$.

\section{Additional file}

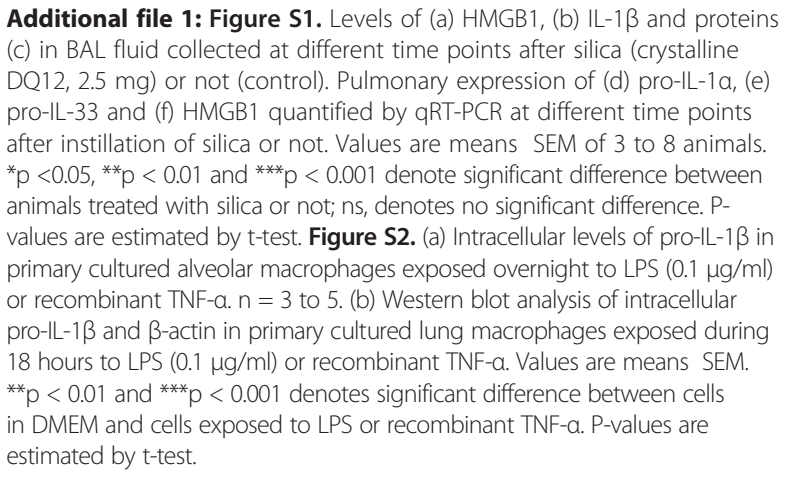

Competing interests

The authors declare that they have no competing interests.

\section{Authors contributions}

VR, AA and FH conceived and designed the experiments. RD, FU, YY, and MP performed the experiments. IC and BR provided mouse strains. VR, AA, DL and $\mathrm{FH}$ analyzed the data. VR, DL and FH wrote the manuscript. All authors read and approved the final manuscript.

\section{Acknowledgements}

This work was funded by the Fonds de la Recherche Scientifique Mdicale (FRSM), by Actions de Recherche Concertes, Communaut franaise de Belgique, Direction de la Recherche Scientifique (ARC 09/14-021), by Fondation Contre le Cancer, by the Fonds de la Recherche Scientifique (FNRS; Project PDR T.0119.13 14633768), by the European Commission under FP7-HEALTH-F4-2008 (Contract no. 202047) and by Agence Nationale de scurit sanitaire de l'alimentation, de l'environnement et du travail (ANSES, France). F.H. is a Research Associate with the FNRS, Belgium.

\section{Author details}

'Louvain centre for Toxicology and Applied Pharmacology (LTAP), Institut de Recherche Exprimentale et Clinique (IREC), Universit catholique de Louvain, Brussels, Belgium. ${ }^{2}$ University of Orlans, CNRS, UMR7355, INEM, Transgenose Institute, Orlans, France. ${ }^{3}$ de Duve Institute, Universit catholique de Louvain, Brussels, Belgium. ${ }^{4}$ Louvain centre for Toxicology and Applied Pharmacology (LTAP), Universit catholique de Louvain (UCL), Avenue Mounier 52, B1.52.12, 1200 Brussels, Belgium.

Received: 1 July 2014 Accepted: 21 November 2014 Published online: 13 December 2014

\section{References}

1. Le Maho S, Bignon J, Lambre C, Jaurand MC, Masse R: Early cellular and biochemical alveolar responses following intra-tracheal inoculation with low dose of asbestos and quartz. Arch Immunol Ther Exp (Warsz) 1984, 32:85 98.

2. Adamson IY, Bowden DH: Crocidolite-induced pulmonary fibrosis in mice. Cytokinetic and biochemical studies. Am J Pathol 1986, 122:261 267.

3. Martinon F, Petrilli V, Mayor A, Tardivel A, Tschopp J: Gout-associated uric acid crystals activate the NALP3 inflammasome. Nature 2006, 440:237 241. 
4. Guo J, Gu N, Chen J, Shi T, Zhou Y, Rong Y, Zhou T, Yang W, Cui X, Chen W: Neutralization of interleukin-1 beta attenuates silica-induced lung inflammation and fibrosis in C57BL/6 mice. Arch Toxicol 2013, 87:1963 1973.

5. Gross O, Yazdi AS, Thomas CJ, Masin M, Heinz LX, Guarda G, Quadroni M, Drexler SK, Tschopp J: Inflammasome activators induce interleukin-1alpha secretion via distinct pathways with differential requirement for the protease function of caspase-1. Immunity 2012, 36:388 400.

6. Hiscott J, Marois J, Garoufalis J, D'Addario M, Roulston A, Kwan I, Pepin N, Lacoste J, Nguyen H, Bensi G, Fenton M: Characterization of a functional NF-kappa B site in the human interleukin 1 beta promoter: evidence for a positive autoregulatory loop. Mol Cell Biol 1993, 13:6231 6240.

7. Cassel SL, Eisenbarth SC, lyer SS, Sadler JJ, Colegio OR, Tephly LA, Carter AB, Rothman PB, Flavell RA, Sutterwala FS: The Nalp3 inflammasome is essential for the development of silicosis. Proc Natl Acad Sci U S A 2008, 105:9035 9040.

8. Leung CC, Yu IT, Chen W: Silicosis. Lancet 2012, 379:2008 2018.

9. Souvannavong $\mathrm{V}$, Adam $\mathrm{A}$ : Macrophages from $\mathrm{C} 3 \mathrm{H} / \mathrm{HeJ}$ mice require an additional step to produce monokines: synergistic effects of silica and poly(I:C) in the release of interleukin 1. J Leukoc Biol 1990, 48:183 192.

10. Meunier E, Coste A, Olagnier D, Authier H, Lefevre L, Dardenne C, Bernad J, Beraud M, Flahaut E, Pipy B: Double-walled carbon nanotubes trigger IL-1 beta release in human monocytes through Nlrp3 inflammasome activation. Nanomedicine 2012, 8:987 995

11. Hornung V, Bauernfeind F, Halle A, Samstad EO, Kono H, Rock KL, Fitzgerald KA, Latz E: Silica crystals and aluminum salts activate the NALP3 inflammasome through phagosomal destabilization. Nat Immunol 2008, 9:847 856 .

12. Gross O, Thomas CJ, Guarda G, Tschopp J: The inflammasome: an integrated view. Immunol Rev 2011, 243:136 151.

13. Rock KL, Lai JJ, Kono $\mathrm{H}$ : Innate and adaptive immune responses to cell death. Immunol Rev 2011, 243:191 205

14. Wei F, Yang D, Tewary P, Li Y, Li S, Chen X, Howard OM, Bustin M, Oppenheim JJ: The Alarmin HMGN1 contributes to antitumor immunity and is a potent immunoadjuvant. Cancer Res 2014, 2014:2014

15. Lamacchia C, Rodriguez E, Palmer G, Gabay C: Endogenous IL-1alpha is a chromatin-associated protein in mouse macrophages. Cytokine 2013, 63:135 144

16. Yang $H$, Wang $H$, Czura CJ, Tracey KJ: The cytokine activity of HMGB1. J Leukoc Biol 2005, 78:1 8.

17. Cogswell JP, Godlevski MM, Wisely GB, Clay WC, Leesnitzer LM, Ways JP, Gray JG: NF-kappa B regulates IL-1 beta transcription through a consensus NF-kappa B binding site and a nonconsensus CRE-like site. J Immunol 1994, 153:712 723 .

18. Lefrancais $E$, Cayrol C: Mechanisms of IL-33 processing and secretion: differences and similarities between IL-1 family members. Eur Cytokine Netw 2012, 23:120 127.

19. Chan JK, Roth J, Oppenheim JJ, Tracey KJ, Vogl T, Feldmann M, Horwood N, Nanchahal J: Alarmins: awaiting a clinical response. J Clin Invest 2012, 122:2711 2719.

20. Lardot CG, Huaux FA, Broeckaert FR, Declerck PJ, Delos M, Fubini B, Lison DF: Role of urokinase in the fibrogenic response of the lung to mineral particles. Am J Respir Crit Care Med 1998, 157:617 628.

21. Huaux F, Lardot C, Arras M, Delos M, Many MC, Coutelier JP, Buchet JP, Renauld JC, Lison D: Lung fibrosis induced by silica particles in NMRI mice is associated with an upregulation of the p40 subunit of interleukin-12 and Th-2 manifestations. Am J Respir Cell Mol Biol 1999, 20:561 572

22. Van Belle AB, de Heusch M, Lemaire MM, Hendrickx E, Warnier G, DunussiJoannopoulos K, Fouser LA, Renauld JC, Dumoutier L: IL-22 is required for imiquimod-induced psoriasiform skin inflammation in mice. J Immunol 2012, 188:462 469

23. Yazdi AS, Guarda G, Riteau N, Drexler SK, Tardivel A, Couillin I, Tschopp $\mathrm{J}$ : Nanoparticles activate the NLR pyrin domain containing 3 (Nlrp3) inflammasome and cause pulmonary inflammation through release of IL-1alpha and IL-1beta. Proc Natl Acad Sci U S A 2010, 107:19449 19454

24. Peeters PM, Perkins TN, Wouters EF, Mossman BT, Reynaert NL: Silica induces NLRP3 inflammasome activation in human lung epithelial cells. Part Fibre Toxicol 2013, 10:3

25. Yang $H$, Lundback $P$, Ottosson L, Erlandsson-Harris $H$, Venereau E, Bianchi ME, Al-Abed Y, Andersson U, Tracey KJ, Antoine DJ: Redox modification of cysteine residues regulates the cytokine activity of high mobility group box-1 (HMGB1). Mol Med 2012, 18:250 259.

26. Venereau E, Casalgrandi M, Schiraldi M, Antoine DJ, Cattaneo A, De Marchis F, Liu J, Antonelli A, Preti A, Raeli L, Shams SS, Yang H, Varani L, Andersson U, Tracey KJ, Bachi A, Uguccioni M, Bianchi ME: Mutually exclusive redox forms of HMGB1 promote cell recruitment or proinflammatory cytokine release. J Exp Med 2012, 209:1519 1528

27. Pauwels NS, Bracke KR, Dupont LL, Van Pottelberge GR, Provoost S, Vanden Berghe T, Vandenabeele P, Lambrecht BN, Joos GF, Brusselle GG: Role of IL-1alpha and the NIrp3/caspase-1/IL-1 beta axis in cigarette smokeinduced pulmonary inflammation and COPD. Eur Respir J 2011, 38:1019 1028.

28. Willart MA, Deswarte K, Pouliot P, Braun H, Beyaert R, Lambrecht BN, Hammad H: Interleukin-1alpha controls allergic sensitization to inhaled house dust mite via the epithelial release of GM-CSF and IL-33. J Exp Med 2012, 209:1505 1517.

29. Hamilton RF Jr, Wu Z, Mitra S, Shaw PK, Holian A: Effect of MWCNT size, carboxylation, and purification on in vitro and in vivo toxicity, inflammation and lung pathology. Part Fibre Toxicol 2013, 10:57.

30. Rock KL, Latz E, Ontiveros F, Kono H: The sterile inflammatory response. Annu Rev Immunol 2010, 28:321 342.

31. Chen GY, Nunez G: Sterile inflammation: sensing and reacting to damage. Nat Rev Immunol 2010, 10:826 837.

32. Dinarello CA: Interleukin-1 in the pathogenesis and treatment of inflammatory diseases. Blood 2011, 117:3720 3732.

33. Hillegass JM, Miller JM, MacPherson MB, Westbom CM, Sayan M, Thompson JK, Macura SL, Perkins TN, Beuschel SL, Alexeeva V, Pass HI, Steele C, Mossman BT, Shukla A: Asbestos and erionite prime and activate the NLRP3 inflammasome that stimulates autocrine cytokine release in human mesothelial cells. Part Fibre Toxicol 2013, 10:39.

34. Dostert C, Petrilli V, Van Bruggen R, Steele C, Mossman BT, Tschopp J: Innate immune activation through Nalp3 inflammasome sensing of asbestos and silica. Science 2008, 320:674 677.

35. Srivastava KD, Rom WN, Jagirdar J, Yie TA, Gordon T, Tchou-Wong KM: Crucial role of interleukin-1beta and nitric oxide synthase in silicainduced inflammation and apoptosis in mice. Am J Respir Crit Care Med 2002, 165:527 533

36. Kono H, Orlowski GM, Patel Z, Rock KL: The IL-1-dependent sterile inflammatory response has a substantial caspase-1-independent component that requires cathepsin C. J Immunol 2012, 189:3734 3740.

37. Botelho FM, Bauer CM, Finch D, Nikota JK, Zavitz CC, Kelly A, Lambert KN, Piper S, Foster ML, Goldring JJ, Wedzicha JA, Bassett J, Bramson J, Iwakura Y, Sleeman M, Kolbeck R, Coyle AJ, Humbles AA, Stmpfli MR: IL-1alpha/IL-1R1 expression in chronic obstructive pulmonary disease and mechanistic relevance to smoke-induced neutrophilia in mice. PLoS One 2011, 6:e28457.

38. Horai R, Asano M, Sudo K, Kanuka H, Suzuki M, Nishihara M, Takahashi M, Iwakura $Y$ : Production of mice deficient in genes for interleukin (IL)-1alpha, IL-1 beta, IL-1alpha/beta, and IL-1 receptor antagonist shows that IL-1beta is crucial in turpentine-induced fever development and glucocorticoid secretion. J Exp Med 1998, 187:1463 1475

39. Franchi L, Nunez G: The Nlrp3 inflammasome is critical for aluminium hydroxide-mediated IL-1beta secretion but dispensable for adjuvant activity. Eur J Immunol 2008, 38:2085 2089.

40. Dinarello CA, Ikejima T, Warner SJ, Orencole SF, Lonnemann G, Cannon JG, Libby P: Interleukin 1 induces interleukin 1. I. Induction of circulating interleukin 1 in rabbits in vivo and in human mononuclear cells in vitro. J Immunol 1987, 139:1902 1910.

41. Suwara MI, Green NJ, Borthwick LA, Mann J, Mayer-Barber KD, Barron L, Corris PA, Farrow SN, Wynn TA, Fisher AJ, Mann DA: IL-1alpha released from damaged epithelial cells is sufficient and essential to trigger inflammatory responses in human lung fibroblasts. Mucosal Immunol 2014, 7:684 693

42. Berda-Haddad Y, Robert S, Salers P, Zekraoui L, Farnarier C, Dinarello CA Dignat-George F, Kaplanski G: Sterile inflammation of endothelial cell-derived apoptotic bodies is mediated by interleukin-1alpha. Proc Natl Acad Sci U S A 2011, 108:20684 20689.

43. Manzer R, Dinarello CA, McConville G, Mason RJ: Ozone exposure of macrophages induces an alveolar epithelial chemokine response through IL-1alpha. Am J Respir Cell Mol Biol 2008, 38:318 323. 
44. Sarih M, Souvannavong V, Brown SC, Adam A: Silica induces apoptosis in macrophages and the release of interleukin-1 alpha and interleukin-1 beta. J Leukoc Biol 1993, 54:407 413.

45. Arnush M, Scarim AL, Heitmeier MR, Kelly CB, Corbett JA: Potential role of resident islet macrophage activation in the initiation of autoimmune diabetes. J Immunol 1998, 160:2684 2691.

46. Luheshi NM, McColl BW, Brough D: Nuclear retention of IL-1 alpha by necrotic cells: a mechanism to dampen sterile inflammation. Eur J Immunol 2009, 39:2973 2980.

47. Reisetter AC, Stebounova LV, Baltrusaitis J, Powers L, Gupta A, Grassian VH, Monick MM: Induction of inflammasome-dependent pyroptosis by carbon black nanoparticles. J Biol Chem 2011, 286:21844 21852.

48. Mossman BT, Churg A: Mechanisms in the pathogenesis of asbestosis and silicosis. Am J Respir Crit Care Med 1998, 157:1666 1680.

49. Warheit DB, McHugh TA, Hartsky MA: Differential pulmonary responses in rats inhaling crystalline, colloidal or amorphous silica dusts. Scand J Work Environ Health 1995, 21(Suppl 2):19 21.

50. Johnston CJ, Driscoll KE, Finkelstein JN, Baggs R, O'Reilly MA, Carter J, Gelein $\mathrm{R}$, Oberdorster $\mathrm{G}$ : Pulmonary chemokine and mutagenic responses in rats after subchronic inhalation of amorphous and crystalline silica. Toxicol Sci 2000, 56:405 413 .

51. Pavan C, Tomatis M, Ghiazza M, Rabolli V, Bolis V, Lison D, Fubini B: In search of the chemical basis of the hemolytic potential of silicas. Chem Res Toxicol 2013, 26:1188 1198.

52. Ghiazza M, Polimeni M, Fenoglio I, Gazzano E, Ghigo D, Fubini B: Does vitreous silica contradict the toxicity of the crystalline silica paradigm? Chem Res Toxicol 2010, 23:620 629.

53. Sandberg WJ, Lag M, Holme JA, Friede B, Gualtieri M, Kruszewski M, Schwarze PE, Skuland T, Refsnes M: Comparison of non-crystalline silica nanoparticles in IL-1beta release from macrophages. Part Fibre Toxicol 2012, 9:32

54. Costantini LM, Gilberti RM, Knecht DA: The phagocytosis and toxicity of amorphous silica. PLoS One 2011, 6:e14647.

55. Hetland RB, Schwarze PE, Johansen BV, Myran T, Uthus N, Refsnes M: Silica-induced cytokine release from A549 cells: importance of surface area versus size. Hum Exp Toxicol 2001, 20:46 55.

56. Sager TM, Wolfarth MW, Andrew M, Hubbs A, Friend S, Chen TH, Porter DW, Wu N, Yang F, Hamilton RF, Holian A: Effect of multi-walled carbon nanotube surface modification on bioactivity in the C57BL/ 6 mouse model. Nanotoxicology 2014, 8:317 327.

57. Beamer CA, Girtsman TA, Seaver BP, Finsaas KJ, Migliaccio CT, Perry VK, Rottman JB, Smith DE, Holian A: IL-33 mediates multi-walled carbon nanotube (MWCNT)-induced airway hyper-reactivity via the mobilization of innate helper cells in the lung. Nanotoxicology 2013, 7:1070 1081.

58. Wang X, Shannahan JH, Brown JM: IL-33 modulates chronic airway resistance changes induced by multi-walled carbon nanotubes. Inhal Toxicol 2014, 26:240 249.

59. Katwa P, Wang X, Urankar RN, Podila R, Hilderbrand SC, Fick RB, Rao AM, Ke PC, Wingard CJ, Brown JM: A carbon nanotube toxicity paradigm driven by mast cells and the IL-(3)(3)/ST(2) axis. Small 2012, 8:2904 2912.

60. Shadie AM, Herbert C, Kumar RK: Ambient particulate matter induces an exacerbation of airway inflammation in experimental asthma: role of interleukin-33. Clin Exp Immunol 2014, 177:491 499.

61. Jessop F, Holian A: Extracellular HMGB1 regulates multi-walled carbon nanotube-induced inflammation in vivo. Nanotoxicology 2014, 1:1 8 [Epub ahead of print].

62. Wahamaa H, Schierbeck H, Hreggvidsdottir HS, Palmblad K, Aveberger AC, Andersson $U$, Harris HE: High mobility group box protein 1 in complex with lipopolysaccharide or IL-1 promotes an increased inflammatory phenotype in synovial fibroblasts. Arthritis Res Ther 2011, 13:R136.

63. Marucha PT, Zeff RA, Kreutzer DL: Cytokine regulation of IL-1 beta gene expression in the human polymorphonuclear leukocyte. J Immunol 1990 145:2932 2937.

64. Black RA, Rauch CT, Kozlosky CJ, Peschon JJ, Slack JL, Wolfson MF, Castner BJ, Stocking KL, Reddy P, Srinivasan S, Nelson N, Boiani N, Schooley KA, Gerhart M, Davis R, Fitzner JN, Johnson RS, Paxton RJ, March CJ, Cerretti DP: A metalloproteinase disintegrin that releases tumour-necrosis factoralpha from cells. Nature 1997, 385:729 733.

65. Shvedova AA, Kisin ER, Mercer R, Murray AR, Johnson VJ, Potapovich Al, Tyurina YY, Gorelik O, Arepalli S, Schwegler-Berry D, Hubbs AF, Antonini J, Evans DE, Ku BK, Ramsey D, Maynard A, Kagan VE, Castranova V, Baron P:
Unusual inflammatory and fibrogenic pulmonary responses to singlewalled carbon nanotubes in mice. Am J Physiol Lung Cell Mol Physiol 2005, 289:L698 L708.

66. Ishii H, Fujii T, Hogg JC, Hayashi S, Mukae H, Vincent R, van Eeden SF: Contribution of IL-1 beta and TNF-alpha to the initiation of the peripheral lung response to atmospheric particulates (PM10). Am J Physiol Lung Cell Mol Physiol 2004, 287:L176 L183.

67. Kocbach A, Herseth JI, Lag M, Refsnes M, Schwarze PE: Particles from wood smoke and traffic induce differential pro-inflammatory response patterns in co-cultures. Toxicol Appl Pharmacol 2008, 232:317 326.

68. Lewis JA, Rao KM, Castranova V, Vallyathan V, Dennis WE, Knechtges PL: Proteomic analysis of bronchoalveolar lavage fluid: effect of acute exposure to diesel exhaust particles in rats. Environ Health Perspect 2007, 115:756 763 .

69. Juang YM, Lai BH, Chien HJ, Ho M, Cheng TJ, Lai CC: Changes in protein expression in rat bronchoalveolar lavage fluid after exposure to zinc oxide nanoparticles: an iTRAQ proteomic approach. Rapid Commun Mass spectrom 2014, 28:974 980

70. Hao HN, Zheng B, Nasser S, Ren W, Latteier M, Wooley P, Morawa L: The roles of monocytic heat shock protein 60 and Toll-like receptors in the regional inflammation response to wear debris particles. J Biomed Mater Res A 2010, 92:1373 1381.

71. Kline JN, Schwartz DA, Monick MM, Floerchinger CS, Hunninghake GW: Relative release of interleukin-1 beta and interleukin-1 receptor antagonist by alveolar macrophages. A study in asbestos-induced lung disease, sarcoidosis, and idiopathic pulmonary fibrosis. Chest 1993, 104:47 53

72. Yucesoy B, Vallyathan V, Landsittel DP, Simeonova P, Luster Ml: Cytokine polymorphisms in silicosis and other pneumoconioses. Mol Cell Biochem 2002, 234 235:219 224.

73. Cohen C, Fireman E, Ganor E, Man A, Ribak J, Lerman Y: Accelerated silicosis with mixed-dust pneumoconiosis in a hard-metal grinder. J Occup Environ Med 1999, 41:480 485.

74. Zhou T, Rong Y, Liu Y, Zhou Y, Guo J, Cheng W, Wang H, Chen W: Association between proinflammatory responses of respirable silica dust and adverse health effects among dust-exposed workers. J Occup Environ Med 2012, 54:459 465

75. Dinarello CA: Blocking IL-1 in systemic inflammation. J Exp Med 2005, 201:1355 1359.

76. Re SL, Yakoub Y, Devosse R, Uwambayinema F, Couillin I, Ryffel B, Marbaix E, Lison D, Huaux F: Uncoupling between inflammatory and fibrotic responses to silica: evidence from MyD88 knockout mice. PLoS One 2014, 9:e99383.

77. Casas JW, Lewerenz GM, Rankin EA, Willoughby JA Sr, Blakeman LC, McKim JM Jr, Coleman KP: In vitro human skin irritation test for evaluation of medical device extracts. Toxicol In Vitro 2013, 27:2175 2183.

78. Kidd DA, Johnson M, Clements J: Development of an in vitro corrosion/ irritation prediction assay using the EpiDerm skin model. Toxicol In Vitro 2007, 21:1292 1297

79. Katoh M, Hamajima F, Ogasawara T, Hata K: Assessment of human epidermal model LabCyte EPI-MODEL for in vitro skin irritation testing according to European Centre for the Validation of Alternative Methods (ECVAM)-validated protocol. J Toxicol Sci 2009, 34:327 334

80. Son D, Na Y, Cho WS, Lee BH, Heo Y, Park JH, Seok SH: Differentiation of skin sensitizers from irritant chemicals by interleukin-1alpha and macrophage inflammatory protein-2 in murine keratinocytes. Toxicol Lett 2013, 216:65 71

81. Thomassen LC, Aerts A, Rabolli V, Lison D, Gonzalez L, Kirsch-Volders M, Napierska D, Hoet PH, Kirschhock CE, Martens JA: Synthesis and characterization of stable monodisperse silica nanoparticle sols for in vitro cytotoxicity testing. Langmuir 2010, 26:328 335

82. Albrecht C, Schins RP, Hohr D, Becker A, Shi T, Knaapen AM, Borm PJ: Inflammatory time course after quartz instillation: role of tumor necrosis factor-alpha and particle surface. Am J Respir Cell Mol Biol 2004, 31:292 301.

83. Clouter A, Brown D, Hohr D, Borm P, Donaldson K: Inflammatory effects of respirable quartz collected in workplaces versus standard DQ12 quartz: particle surface correlates. Toxicol Sci 2001, 63:90 98.

84. Rabolli V, Wallemme L, Lo Re S, Uwambayinema F, Palmai-Pallag M, Thomassen L, Tyteca D, Octave JN, Marbaix E, Lison D, Devuyst O, Huaux F: Critical role of aquaporins in IL-1 beta-mediated inflammation. J Biol Chem 2014, 289:13937 13947. 
85. Nymark P, Jensen KA, Suhonen S, Kembouche Y, Vippola M, Kleinjans J, Catalan J, Norppa H, van Delft J, Briede JJ: Free radical scavenging and formation by multi-walled carbon nanotubes in cell free conditions and in human bronchial epithelial cells. Part Fibre Toxicol 2014, 11:4.

86. Rabolli V, Lo Re S, Uwambayinema F, Yakoub Y, Lison D, Huaux F: Lung fibrosis induced by crystalline silica particles is uncoupled from lung inflammation in NMRI mice. Toxicol Lett 2011, 203:127 134.

doi:10.1186/s12989-014-0069-x

Cite this article as: Rabolli et al.: The alarmin IL-1a is a master cytokine

in acute lung inflammation induced by silica micro- and nanoparticles. Particle and Fibre Toxicology 2014 11:69.

\section{Submit your next manuscript to BioMed Central and take full advantage of:}

$\otimes$ Convenient online submission

$\otimes$ Thorough peer review

$\bigotimes$ No space constraints or color $\bowtie$ gure charges

$\otimes I m m e d i a t e$ publication on acceptance

\Inclusion in PubMed, CAS, Scopus and Google Scholar

$\otimes$ Research which is freely available for redistribution 